\title{
Root-Zone Soil Water Balance and Sunflower Yield under Deficit Irrigated in Zambia
}

\author{
Elijah Phiri' ${ }^{1}$, Simon Zimba ${ }^{2}$ \\ ${ }^{1}$ Department of Soil Science, School of Agricultural Sciences, University of Zambia, Lusaka, Zambia \\ ${ }^{2}$ Natural Resources Development College, Lusaka, Zambia \\ Email:ephiri@unza.zm
}

How to cite this paper: Phiri, E. and Zimba, S. (2018) Root-Zone Soil Water Balance and Sunflower Yield under Deficit Irrigated in Zambia. Open Journal of Soil Science, 8, 61-73.

https://doi.org/10.4236/ojss.2018.81005

Received: October 28, 2017

Accepted: January 23, 2018

Published: January 26, 2018

Copyright () 2018 by authors and Scientific Research Publishing Inc. This work is licensed under the Creative Commons Attribution International License (CC BY 4.0).

http://creativecommons.org/licenses/by/4.0/

(c) (i) Open Access

\begin{abstract}
The study was conducted at the University of Zambia, Research Field Station, Lusaka, Zambia to evaluate the root zone soil water balance under full, and deficit irrigated sunflower. The specific objectives were: 1 ) to assess the sunflower growth and yield under varying irrigation water regimes; 2 ) to evaluate the root-zone water balance; and 3) to evaluate the water use efficiency of sunflower. Sunflower (Helianthus annuus, var Milika) was planted in a Randomized Complete Block Design (RCBD) with four irrigated water regimes in four replications. The treatments comprised: treatment $(\mathrm{T} 1)=30 \% \mathrm{ETc}$; treatment $(\mathrm{T} 2)=54 \% \mathrm{ETc}$; treatment $(\mathrm{T} 3)=65 \% \mathrm{ETc}$; and treatment $(\mathrm{T} 4)=$ $100 \%$ ETc. The sunflower crop was irrigated on a weekly irrigation schedule using sprinklers. The measured parameters included: weather data, soil moisture profiles, growth stages (emergence, flowering, maturity), above-ground biomass, and grain yield. The results of the study showed that growth parameter (biomass and seed yield) decreased with a decrease in applied irrigation water. The sunflower seed yield varied from 0.22 to 1.40 -ton.ha ${ }^{-1}$ with an average yield of 0.81 -ton $\cdot \mathrm{ha}^{-1}$. The highest grain yield was obtained under treatment (T4), and the least grain in yield harvest was at treatment (T1). The statistical analysis showed significant differences in seed yield among the treatments. The treatments ( $\mathrm{T} 1$ and $\mathrm{T} 2$ ) were not significantly different ( $p>0.05$ ). These results showed that when water deficit was set at $65 \%$ and $100 \%$ ETc and uniformly distributed throughout the sunflower growth, there were no significant differences in biomass, stover and seed yield. In literature, the allowable soil moisture depletion factor for irrigation scheduling of sunflower is set at $45 \%$. The yield components decreased as irrigation levels decreased for each irrigation interval. The $65 \%$ ETc treatment could be recommended for sunflower irrigated in semi-arid regions and be used as a good basis for improved irrigation strategy development under water stressed environment.
\end{abstract}




\section{Keywords}

Crop Water Requirements, Water Use Efficiency, Sprinkler Irrigation, Water Productivity

\section{Introduction}

Globally irrigated agriculture uses about $72 \%$ of available fresh water resources [1]. The world population and its corresponding demand for extra water force the agricultural sector to use irrigated water more efficiently for food production. Defining optimum strategies for sustainable management of available fresh water resources is becoming a priority for the agricultural sector [2]. Promising irrigation strategies in agriculture water management have been observed under deficit irrigation [1] [3]-[10]. The physical model of water flux in the Soil-Plant-Atmosphere Continuum (SPAC) is primarily controlled by the hydraulic resistances in the root, stem, leaf, stomata and cuticular is the basis of our understanding of plant water relations. The SPAC is the pathway for water moving from soil through plants to the atmosphere. The continuous nature of water connection through the pathway is a result of the low water potential of the atmosphere, and relatively higher water potential inside leaves leads to a diffusion gradient across the stoma

Sunflower (Helianthus annuus L.), an important oil crop, ranks second to soybean oil regarding global vegetable oil. The high ratio of polyunsaturated fatty acids and its excellent stability characteristics make its oil highly attractive for domestic and industrial use. High protein sunflower meal and whole sunflower kernels form part of human food formulations. Knowledge of sunflower production and water productivity under water stress conditions is becoming increasingly important in the advent of climate change and variability. The prediction of the sunflower yield and the yield response to water is critical for developing strategies for irrigation management that support related farmers' decision-making under limited water availability conditions. The current production of 46.6 estimated million tons represents a modest increase of $15.5 \%$ worldwide. Such global statistics mask the much greater expansion of sunflower production that has taken place in developing countries versus developed countries during the past 40 years. Much of the increase in sunflower production in developing countries has occurred in Asia, most notably in China and India. The study was conducted to evaluate the soil water balance under deficit irrigation of sunflower crop.

\section{Materials and Methods}

\subsection{Study Area}

The study site was located at the University of Zambia, Lusaka, Zambia (long: $28^{\circ} 20^{\prime} 13^{\prime \prime}$ and lat: $15^{\circ} 23^{\prime} 42$, and $1160 \mathrm{~m}$ above sea level). The long-term average rainfall with $95 \%$ confidence level ranges from 750 to $970 \mathrm{~mm}$ with resulting av- 
erage of $860 \mathrm{~mm}$ and effective rainfall of $622 \mathrm{~mm}$ received within 86 rainy-days. According to the Koeppen climate classification, the experimental site falls under warm temperate with dry winter and hot summer (Cwa). The site is under dry sub-humid with aridity index of 0.57 . The climatic net primary production potential (NPP) of the site $1.3 \mathrm{Kg} \mathrm{DM} / \mathrm{m}^{2} /$ year which is primarily limited by precipitation according to the Miami model (Lieth, 1972). Figure 1 showed the long-term monthly rainfall and reference evapotranspiration of the study site.

\subsection{Description of Materials and Experimental Treatments}

Sunflower, a hybrid (Milika variety), was planted in a randomized complete block design (RCBD) with four (4) treatments and four replications. The treatments consisted of: treatment $(\mathrm{T} 1)=70 \mathrm{~mm}(30 \% \mathrm{ETc})$; treatment $(\mathrm{T} 2)=211$ $\mathrm{mm}(54 \% \mathrm{ETc})$; treatment $(\mathrm{T} 3)=297 \mathrm{~mm}(65 \% \mathrm{ETc})$; and treatment $(\mathrm{T} 4)=481$ $\mathrm{mm}(100 \% \mathrm{ETc})$. Planting density was $75 \mathrm{~cm}$ between rows and $30 \mathrm{~cm}$ between plants resulting in a plant density of 45,000 plants per hectare. The basal dressing (D-compound) fertilizer was applied at the rate of $200 \mathrm{~kg} / \mathrm{ha}$, and top dressing (urea) applied at $120 \mathrm{~kg} / \mathrm{ha}$.

PVC access tubes $(\varnothing=50 \mathrm{~mm})$ were installed in the center of each plot to enable monitoring of soil moisture profiles. Soil moisture was measured at 0.15 $\mathrm{m}$ interval up to a depth of $1.50 \mathrm{~m}$ using a neutron probe (Campbell Pacific Model 503 DR Hydro probe). Water was applied weekly using sprinkler irrigation system. The moisture probe was calibrated using the gravimetric method.

\subsection{Irrigation Application}

The crop evapotranspiration for irrigation scheduling was determined from the crop coefficient $(\mathrm{Kc})$ and calculated reference evapotranspiration (ETo), using the ETo calculator [1] from historical weather data using the Penman-Monteith (PM) equation which is most widely used for computing daily ETo [11].

The FAO PM equation [11] is given by:

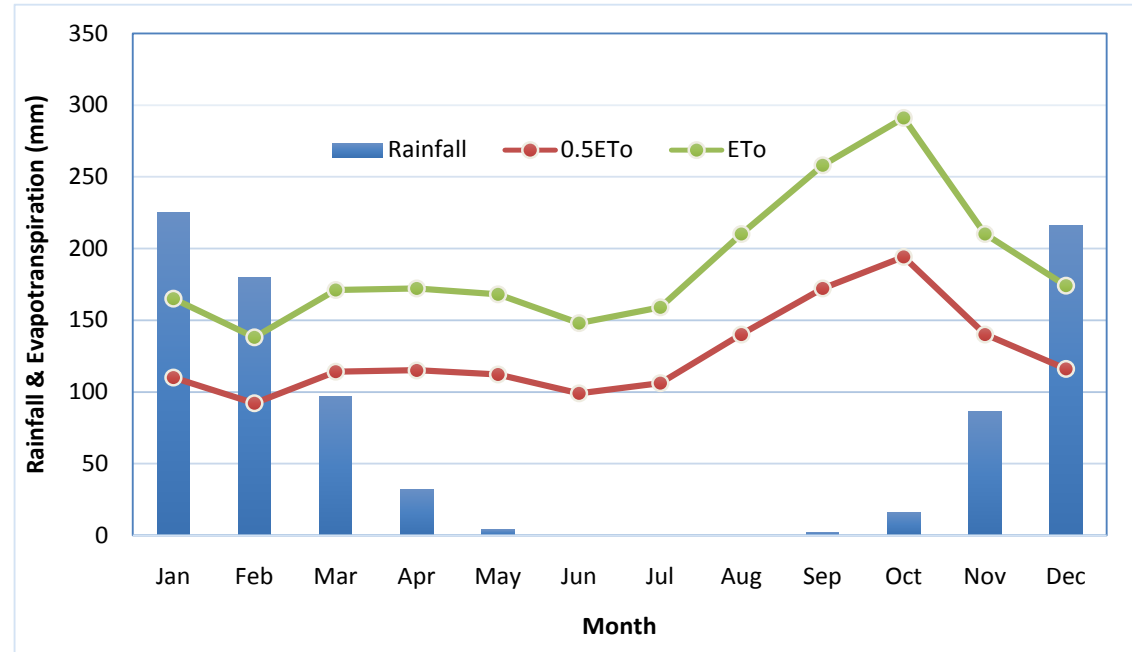

Figure 1. Long-term average monthly rainfall $(\mathrm{mm})$ and evapotranspiration $(\mathrm{mm})$. 


$$
E T_{o}=\frac{0.408 \Delta\left(R_{n}-G\right)+\gamma \frac{900}{T+273} U_{2}\left(e_{s}-e_{a}\right)}{\Delta+\gamma\left(1+0.34 u_{2}\right)}
$$

where $E T_{\mathrm{o}}$ is reference evapotranspiration $\left(\mathrm{mm} \cdot \mathrm{day}^{-1}\right), R_{n}=$ net radiation at crop surface $\left(\mathrm{MJm}^{-2} \cdot\right.$ day $\left.^{-1}\right), G=$ Soil heat flux density $\left(\mathrm{MJm}^{-2} \cdot \mathrm{day}^{-1}\right)$, Mean daily temperature at $2 \mathrm{~m}$ height $\left({ }^{\circ} \mathrm{C}\right), U_{2}=$ wind speed at $2 \mathrm{~m}$ height $(\mathrm{m} / \mathrm{s}), e_{s}=$ saturation vapour pressure $(\mathrm{kPa})$ and $e a=$ saturation vapour pressure, $\Delta=$ slope vapour pressure curve $\left(\mathrm{kPa} \cdot{ }^{\circ} \mathrm{C}^{-1}\right)$ and $\gamma=$ Psychrometric constant $\left(\mathrm{kPa} \cdot{ }^{\circ} \mathrm{C}^{-1}\right)$.

\subsection{Crop Evapotranspiration}

Crop evapotranspiration (ET) of sunflower plant sunder varying irrigation amounts was calculated with the root zone soil water balance equation [12] with negligible runoff.

$$
E T_{C}=I+P+S+Q
$$

In the equation, crop evapotranspiration is denoted with $E T(\mathrm{~mm})$, the amount of irrigation water applied with $I(\mathrm{~mm})$, rainfall with $P(\mathrm{~mm})$, variations in the root zone soil water storage with $\Delta S(\mathrm{~mm})$, and deep percolation with $\mathrm{Q}(\mathrm{mm})$ below the root zone. The difference between the inputs and the outputs of the root zone water balance model was used in ET calculation procedure [13] [14].

\subsection{Water Use Efficiency}

Water-use efficiency ( $W U E$ ) is an important determinant of plant production under most conditions of limited water supply. It implies that rainfed plant production can be increased per unit water used, resulting in "more crop per drop":

$$
W U E=\frac{Y}{E T o}
$$

On dry matter basis, water use efficiency ( $W U E$ ), was calculated as follows: where $Y=$ harvested yield $\left(\mathrm{kg} \cdot \mathrm{DM} \cdot \mathrm{m}^{-2}\right)$ and $E T o=$ Total growing period evapotranspiration $(\mathrm{mm})$.

\subsection{Statistical Evaluation}

Analysis of variances (ANOVA) of data for each measured parameter was conducted to evaluate the effects of the treatments on seed sunflower yield, root-zone soil water balance, and water use efficiency by using R Software (version 3.4.0). The Least Significant Differences (LSD) test was used for comparing treatments means with differences declared at significant of $\mathrm{p}<0.05$.

\section{Results and Discussion}

\subsection{Soil Chemical and Physical Properties}

The results on the chemical and physical properties of the studied soil at the ex- 
perimental site are presented in Table 1, Table 2 and Table 3 . The soil reaction $(\mathrm{pH})$ for the surface soil varied from 6.6 to 7.4 with an average of 7.1. The soil indicates moderate soil fertility status with average organic carbon and total nitrogen content of $1.75 \%$ and $1.41 \%$, respectively. The soil is well drained and strongly weathered dark reddish brown with a loam top-soil underlain by clay subsoil. The soil was classified as fine-loam iso-hyperthermic Paleustalf according to USDA classification [15]. The soil was slightly acidic to alkaline with low quantities of available phosphorus and exchangeable potassium.

Results on soil physical properties from a representative soil profile are presented in Table 2 . The soil bulk density varied from 1.5 to $1.6 \mathrm{~g} / \mathrm{cm}^{2}$ with an average of $1.55 \mathrm{~g} / \mathrm{cm}^{3}$. The average soil moisture content at field capacity and the wilting point was $0.30 \mathrm{~cm}^{3} / \mathrm{cm}^{3}$ and $0.12 \mathrm{~cm}^{3} / \mathrm{cm}^{3}$ respectively resulting in the available water-holding capacity of $180 \mathrm{~mm} / \mathrm{m}$. The texture of the soil profile has a loamy top-soil underlain by clay subsoil.

The soil hydraulic properties as described by the van Genuchten equation [16] are presented in Table 3. The results on soil water content at saturation and residual moisture varied from 0.379 to 0.424 and 0.065 to $0.088 \mathrm{~cm}^{3} / \mathrm{cm}^{3}$, respectively indicating some soil uniformity with depth. Similarly, the saturated hydraulic conductivity ranged from $41 \mathrm{~mm} / \mathrm{d}$ to $55 \mathrm{~mm} / \mathrm{d}$ with an average of 48 $\mathrm{mm} / \mathrm{d}$.

\subsection{Irrigation Application}

Results on the monthly crop evapotranspiration, rainfall and irrigation treatments during the sunflower growth are presented in Figure 2. The treatments were $\mathrm{T} 1=70 \mathrm{~mm}(30 \%), \mathrm{T} 2=211 \mathrm{~mm}(54 \%), \mathrm{T} 3=297 \mathrm{~mm}(65 \%)$ and $\mathrm{T} 4=481$ $\mathrm{mm}(100 \%)$ of the crop water requirements evenly spread throughout the growing period of irrigated sunflower crop growth.

\subsection{Descriptive Statistics of the Measured Parameters}

Results on the descriptive statistics of the frequencies of residuals and fitted values for soil water balance parameters namely: a) change in soil water storage; b)

Table 1. Selected soil chemical characteristic of the top $0.20 \mathrm{~m}$ depth of the experimental site.

\begin{tabular}{ccc}
\hline Soil property & Range & Mean \\
\hline Soil reaction $(\mathrm{pH})$ & $6.67-7.41$ & 7.14 \\
Organic carbon $(\%)$ & $0.94-3.35$ & 1.75 \\
Exch. Ca $(\mathrm{cmol} / \mathrm{kg})$ & $28.00-58.75$ & 37.00 \\
Exch. $\mathrm{Mg}(\mathrm{cmol} / \mathrm{kg})$ & $6.25-11.66$ & 9.21 \\
Exch. K (cmol/kg) & $0.10-0.26$ & 0.17 \\
Available P (mg/kg soil) & $2.90-9.75$ & 4.90 \\
Total Nitrogen $(\%)$ & $0.15-1.44$ & 1.41 \\
\hline
\end{tabular}


Table 2. Soil physical properties, bulk density $\left(\rho_{b}\right)$, and texture and water retention from experimental site.

\begin{tabular}{ccccccccc}
\hline $\begin{array}{c}\text { Soil } \\
\text { depth }\end{array}$ & $\rho_{b}$ & Sand & Silt & Clay & $\begin{array}{c}\text { Textural class } \\
\text { (USDA) }\end{array}$ & FC & WP & AWC \\
\hline$(\mathrm{cm})$ & $\left(\mathrm{g} / \mathrm{cm}^{3}\right)$ & $(\%)$ & $(\%)$ & $(\%)$ & USDA & $(\mathrm{v} / \mathrm{v})$ & $(\mathrm{v} / \mathrm{v})$ & $(\mathrm{mm} / \mathrm{m})$ \\
\hline $0-20$ & 1.58 & 42 & 32 & 26 & Loam & 0.280 & 0.078 & 202 \\
$20-45$ & 1.57 & 24 & 34 & 42 & Clay & 0.297 & 0.124 & 173 \\
$45-80$ & 1.56 & 28 & 32 & 40 & Clay & 0.303 & 0.126 & 177 \\
$80-120$ & 1.53 & 22 & 34 & 44 & Clay & 0.313 & 0.132 & 181 \\
\hline
\end{tabular}

$\mathrm{FC}=$ field capacity; $\mathrm{WP}=$ wilting point; $\mathrm{AWC}=$ available water-holding capacity; $p_{b}=$ bulk density.

Table 3. Soil hydraulic properties of a representative soil profile at the study site.

\begin{tabular}{cccccc}
\hline Soil depth & $\theta_{\boldsymbol{s}}$ & $\theta_{\boldsymbol{r}}$ & $\boldsymbol{\alpha}$ & $\boldsymbol{N}$ & $\boldsymbol{K} \boldsymbol{s}$ \\
\hline$(\mathrm{cm})$ & $(\mathrm{v} / \mathrm{v})$ & $(\mathrm{v} / \mathrm{v})$ & $\left(\mathrm{cm}^{-1}\right)$ & (unitless) & $(\mathrm{mm} / \mathrm{d})$ \\
\hline $0-20$ & 0.379 & 0.065 & 0.0147 & 1.3751 & 55.4 \\
$20-45$ & 0.410 & 0.085 & 0.0142 & 1.3183 & 41.4 \\
$45-80$ & 0.409 & 0.083 & 0.0145 & 1.3228 & 45.0 \\
$80-120$ & 0.424 & 0.088 & 0.0143 & 1.324 & 51.8 \\
\hline
\end{tabular}

$\theta_{s}=$ saturated soil moisture; $\theta_{\mathrm{r}}=$ residue soil moisture; $K s=$ saturated hydraulic conductivity; $\alpha, N$, and $\mathrm{m}=$ van Genuchten curve fitting parameters for soil moisture retention curve.

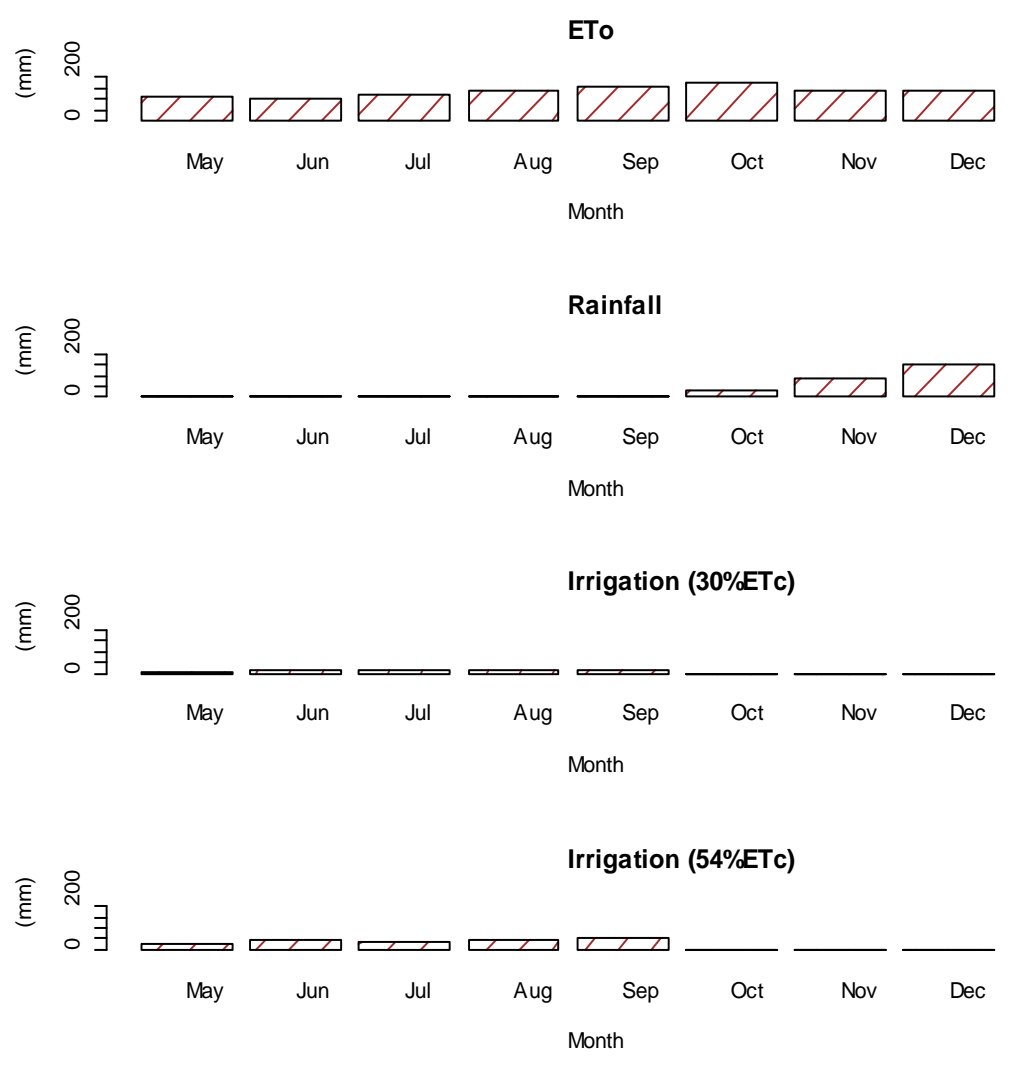

(a) 


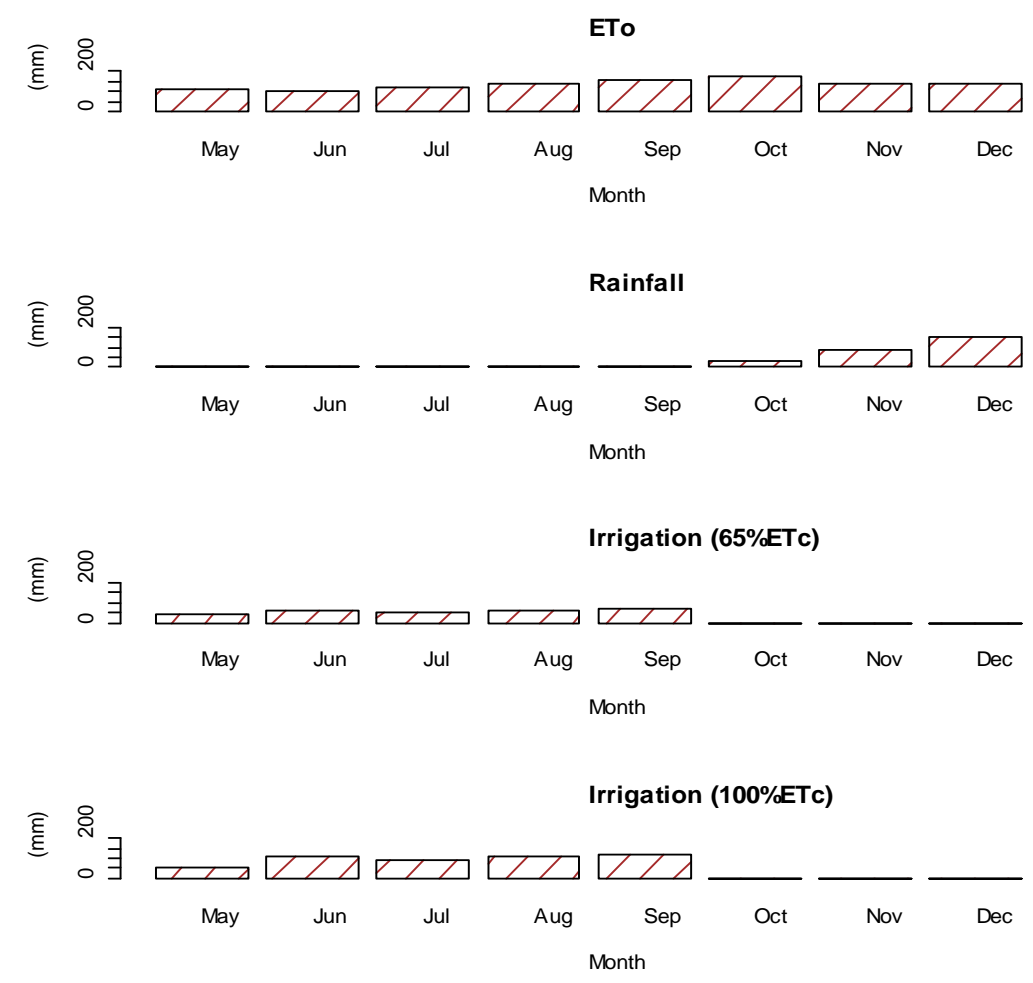

(b)

Figure 2. Evapotranspiration, rainfall and irrigation treatments during experiment period.

drainage below the crop root zone; and c) crop evapotranspiration are presented in Figures 3(a)-(c). The residuals indicate a normal distribution and randomly fitted values to the statistical model for ANOVA reflecting the random part of the model [17].

Similarly, the results on the descriptive statistics of the frequencies of residuals and fitted values for soil water balance parameters, namely: a) aboveground biomass; b) stover; and c) seed yield for sunflower are presented in Figure 4. The residuals indicate a normal distribution and randomly fitted values to the statistical model for ANOVA.

Results on the descriptive statistics of the frequencies of residuals and fitted values for soil water balance parameters, namely: a) harvest index; b) aboveground biomass, water use efficiency; and c) seed yield are presented in Figure 5. The residuals indicate a positively skewed distribution and randomly fitted values to the statistical model for an analyzed variance.

\subsection{Crop Growth}

\subsubsection{Aboveground Biomass}

Results of aboveground biomass of sunflower are presented in Figure 6. The above ground biomass varied from 0.83 to 4.18 tons /ha with an average of 2.73 tons/ha. There were significant differences observed in the above-ground biomass. The treatments under 30\% (T1) and 54\% ETc (T2) were not significantly 

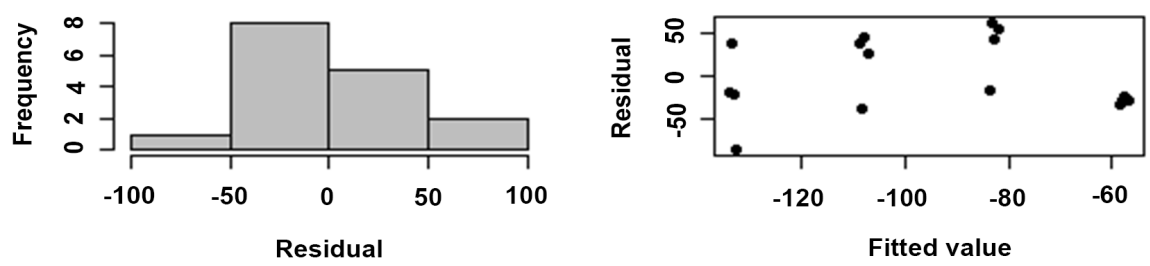

(a)
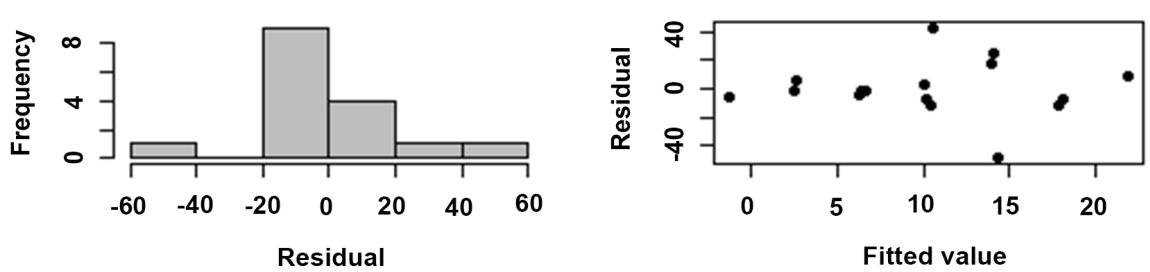

(b)
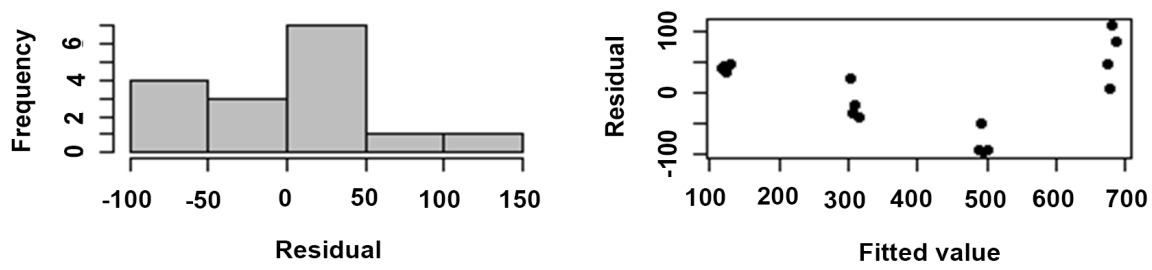

(c)

Figure 3. Frequency of residuals and fitted values for (a) change in soil water storage, (b) drainage, and (c) crop evapotranspiration.
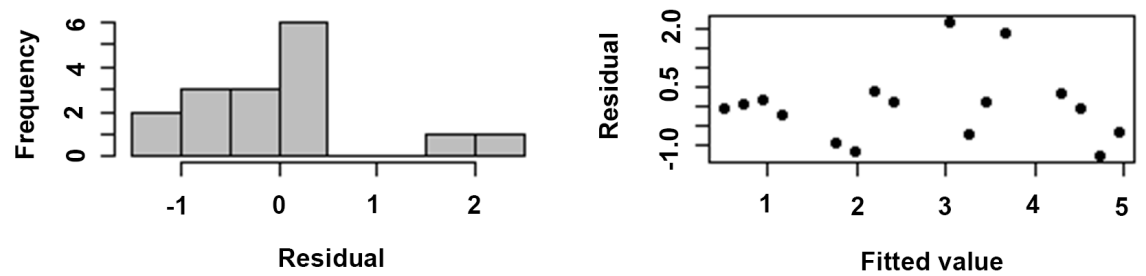

(a)
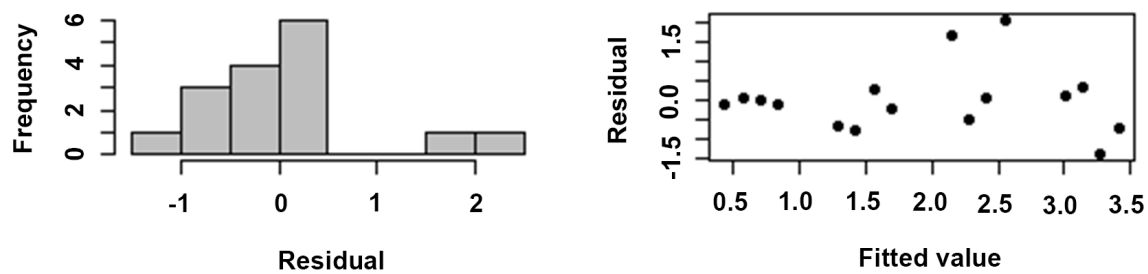

(b)
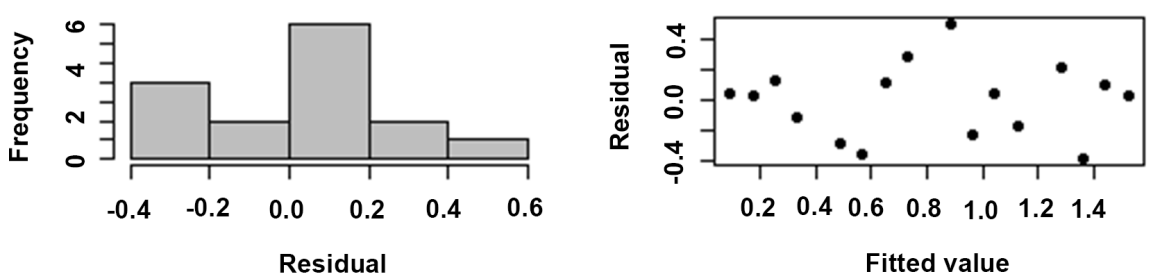

(c)

Figure 4. Frequency of residuals and fitted values for (a) aboveground biomass, (b) stover, and (c) seed yield. 

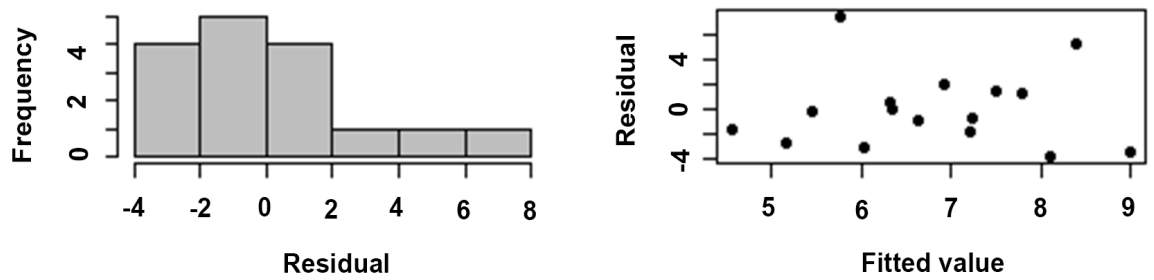

(a)
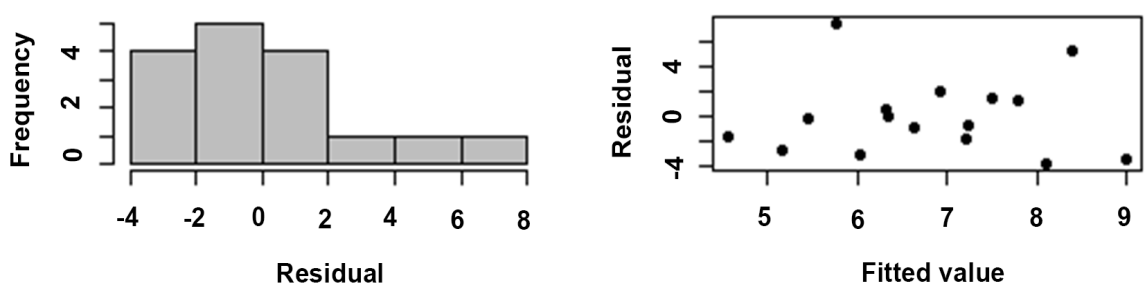

(b)
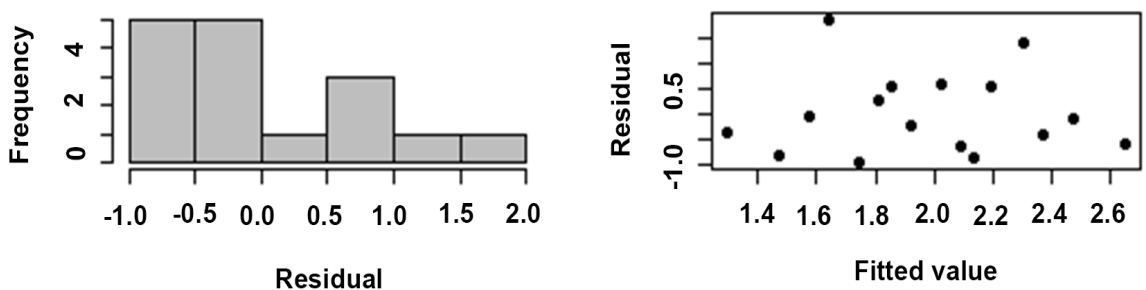

(c)

Figure 5. Frequency of residuals and fitted values for (a) harvest index, (b) Biomass WUE, and (c) Seed yield WUE.

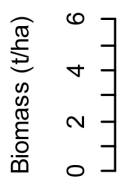

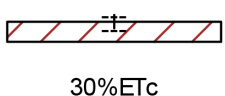

$30 \%$ ETC

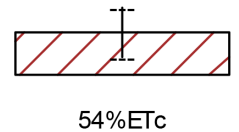

(a)

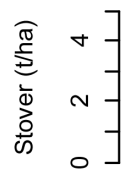
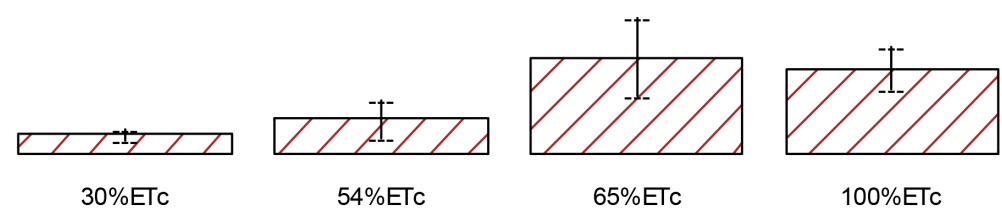

(b)
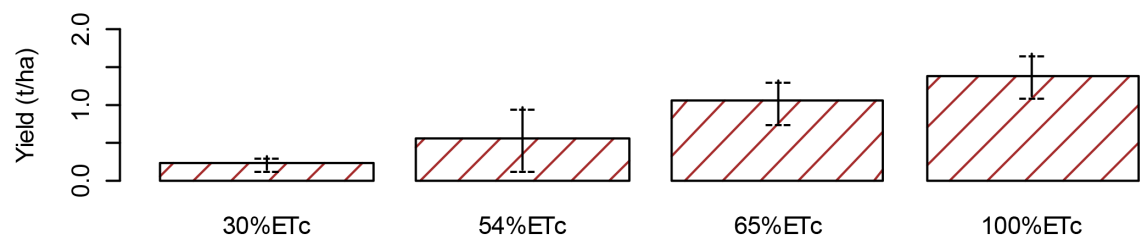

(c)

Figure 6. Effect deficit irrigation rate on (a) aboveground biomass, (b) stover and (c) seed yield of sunflower crop. 
different $(\mathrm{p}>0.05)$. Similarly, the treatments under 65\% (T3) and 100\% ETc (T4) were also not significantly different $(p>0.05)$. However, these two groups of treatment were significantly different from each other. The treatments on aboveground biomass under $30 \%$ and $54 \%$ ETc were significantly different from treatments under $65 \%$ and $100 \%$ ETc. These results showed that the allowable soil moisture depletion factor should be lower than 65\% $(\mathrm{p}=0.65)$ for irrigation water application so that no significant reduction in plant growth was observed.

\subsubsection{Stover Yield}

Results on stover yield are presented in Figure 6. The stover yield ranged from 0.60 to 3.18 tons/ha with an average mean of 1.92 tons/ha. The irrigation treatments showed significant differences in the stover harvested. The treatments under 30\% (T1) and 54\% ETc (T2) were not significantly different (P > 0.05) while the treatments under $65 \%$ (T3) and $100 \%$ ETc (T4) were also not significantly different. Similar to biomass yield, stover yield between treatment groups of $\mathrm{T} 1$ and $\mathrm{T} 2$, and groups $\mathrm{T} 3$ and $\mathrm{T} 4$ were significantly different.

\subsubsection{Grain Yield}

Results of harvested seed yield are presented in Figure 6. The sunflower seed yield varied from 0.230 to 1.40 ton/ha with an average yield of 0.81 ton/ha. The highest grain yield was observed under treatment (T4), and the least grain in yield harvest was observed under treatment (T1). The statistical analysis showed significant differences in grain yield among the treatments. The treatments (T1 and T2) were not significantly different $(\mathrm{p}>0.05)$. However, there was significant differences in seed yield among the treatment group (T1 and T2) treatment (T3) and treatment (T4) respectively $(\mathrm{p}<0.05)$. Again, these results on seed yield indicate that there were no significant differences between treatment under $65 \%$ and $100 \%$ ETc irrigation regime. These results showed that when water deficit is set at $65 \%$ and $100 \%$ ETc and uniformly distributed throughout the sunflower growth, there are no significant differences in biomass, stover and seed yield. In literature, the allowable soil moisture depletion factor for irrigation scheduling of sunflower is set at $45 \%$.

Results from descriptive statistics of the frequencies of residues and fitted values for measured sunflower growth parameters indicated that residues were roughly normally distributed, independently and randomly fitted to the statistical model for analysis of variance.

\subsection{Soil Water Balance}

\subsubsection{Change in storage $(\Delta S)$}

The results for the change in soil moisture storage in the root zone are presented in Table 4. The change in soil moisture storage varied from -156.2 to $-86.8 \mathrm{~mm}$ with an average of $-95.3 \mathrm{~mm}$ indicating a depleted soil profile at harvest. The highest change in soil moisture storage was observed under T1 (30\% ETc) while the least change was observed under T4 (100\% ETc). There were significant differences in change in the root-zone soil moisture storage. There were no 
Table 4. Effects of deficit irrigation on soil water balance components.

\begin{tabular}{cccccc}
\hline Treatment & Rainfall & Irrigation & ETc & $Q$ & $\Delta S$ \\
\hline T1 (\%30 ETc) & 18 & $(\mathrm{~mm})$ & $(\mathrm{mm} / \mathrm{d})$ & $(\mathrm{mm})$ & $(\mathrm{mm})$ \\
T2 (\%54 ETc) & 45 & 70 & $163.0^{\mathrm{a}}$ & 2.0 & $-86.8^{\mathrm{a}}$ \\
T3 (\%65 ETc) & 36 & 211 & $291.4^{\mathrm{b}}$ & 11.9 & $-47.8^{\mathrm{a}}$ \\
T4 (\%100 ETc) & & 481 & $411.5^{\mathrm{c}}$ & 12.1 & $-90.6^{\mathrm{a}}$ \\
Mean & & & $742.4^{\mathrm{d}}$ & 15.0 & $-156.2^{\mathrm{b}}$ \\
CV & & $402.1^{* * *}$ & $10.3^{\mathrm{ns}}$ & -95.3 \\
P.F & & 6.8 & 180.3 & 37.2 \\
\hline
\end{tabular}

$\mathrm{ETc}=$ crop evapotranspiration in $\mathrm{mm} \cdot \mathrm{d}^{-1} ; Q=$ soil water content in $\mathrm{mm}$ and $\Delta S=$ change of water storage in $\mathrm{mm}$, WUEb = water use efficiency in $\mathrm{kg} \cdot \mathrm{m}^{-2} / \mathrm{ha}$; WUEg = water use efficiency in $\mathrm{kg} \cdot \mathrm{m}^{-2} / \mathrm{ha}$; and ET $c$ and $\Delta S$ values with the same superscript indicates that there are not significantly different at $\mathrm{p}<0.05$.

significant differences among treatments $\{(\mathrm{T} 1(30 \% \mathrm{ETc}), \mathrm{T} 2(54 \% \mathrm{ETc})$ and $\mathrm{T} 3$ $(65 \% \mathrm{ETc})\}(\mathrm{p}<0.05)$. However, the treatment group (T1, T2 and T3) was significantly different from treatment $(\mathrm{T} 4)(\mathrm{p}<0.05)$.

\subsubsection{Drainage}

Results on drainage occurring below the root-zone are presented in Table 4. Seasonal drainage varied from $2 \mathrm{~mm}$ to $15 \mathrm{~mm}$ with an average of $10.3 \mathrm{~mm}$. There were no significant differences in the drainage below the root zone. Thus, indicates that the treatments did not differ in their drainage pattern as most of the water was used up as crop uptake.

\subsubsection{Water Use Efficiency}

The results of biomass water use efficiency (WUEb) of sunflower at harvest are presented in Figure 7. The water use efficiency varied from 5.17 to $10.37 \mathrm{~kg}$ $\mathrm{DM} / \mathrm{m}^{-2} / \mathrm{ha}$. The highest water use efficiency for biomass was obtained under treatment $\mathrm{T} 3(65 \% \mathrm{ETc})$, and the lowest was obtained in $\mathrm{T} 1$ (30\% ETc). The results on water use efficiency showed that there were no significant differences ( $\mathrm{p}>0.05$ ) in water use efficiency biomass among treatments (T1, T2, and T4). However, there were significant differences between the group (T1, T2, and T4) and treatment (T3) $(\mathrm{p}<0.05)$.

The results on water use efficiency of seed yield are presented in Figure 7. The water use efficiency (WUEg) of seed yield ranged from 1.51 to $2.57 \mathrm{~kg} \cdot \mathrm{m}^{-3} / \mathrm{ha}$, and the average was $6.78 \mathrm{~kg} \cdot \mathrm{m}^{-3} / \mathrm{ha}$. The highest WUEg was obtained under T3 (65\% ETc), and the least value was recorded under T1 (30\% ETc). The results showed no significant differences among treatments $(\mathrm{p}>0.05)$. The results revealed that deficit irrigation uses water efficiently.

\section{Conclusions and Recommendations}

The results for the components of the root-zone soil moisture indicated that crop water use, drainage below the root-zone and change in soil moisture 


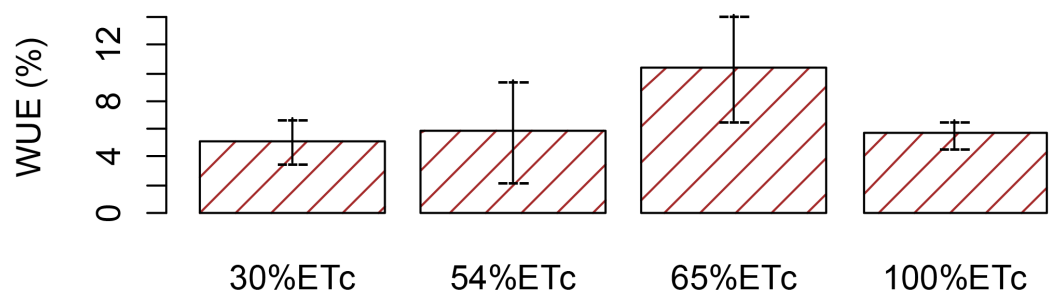

(a)
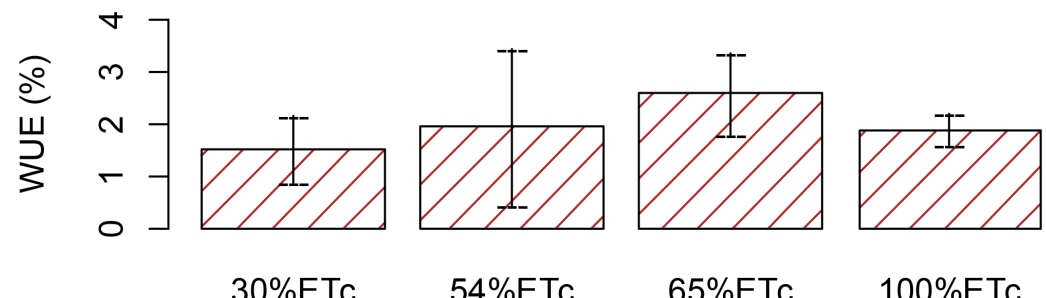

(b)

Figure 7. Effect deficit irrigation rate on water use efficiency for (a) aboveground biomass and (b) seed yield of sunflower crop.

storage increased with increased irrigation water application The results also significantly demonstrated the effects of the amount of the irrigation water as a major factor for obtaining higher yields of sunflower production under Zambian conditions. Irrigation levels had significant effects on the yield and yield components of sunflower and the root-zone soil water balance. The maximum average yield was obtained from T4 $(100 \% \mathrm{ETc})$ treatment as averaging 1.40 -ton $\cdot \mathrm{ha}^{-1}$ which was not significantly different from $\mathrm{T} 3(65 \% \mathrm{ETc})$ treatment indicating definite crop water requirements for sunflower growth.

The results indicated that the WUE values decreased with the increasing irrigation level. The highest WUE was obtained at T3 (65\% ETc) of the irrigation level. However, the lowest irrigation levels resulted in lower seed yields with significant relationships between seed yield and the seasonal water use for each irrigation level in this study. Based on our results, irrigation with an approximate threshold of $65 \%$ Etc for targeting soil profile water extraction could be considered as a strategic irrigation water application to save water while maximizing WUE under limited water abundant conditions. Therefore T4 (65\% ETc) treatment is recommended for sprinkler irrigated sunflower for obtaining higher yield and water use efficiency.

\section{Acknowledgments}

The authors thank the Department of Soil Science at the University of Zambia for providing the necessary facilities. We also thank the technicians Edward Bwalya, Stanley Phiri, and Sandram Sakala for his valuable contribution during data collection.

\section{References}

[1] Geerts, S. and Raes, D. (2009) Deficit Irrigation as an On-Farm Strategy to Maxim- 
ize Crop Water Productivity in Dry Areas. Agricultural Water Management, 96, 1275-1284. https://doi.org/10.1016/j.agwat.2009.04.009

[2] Smith, M. (2000) The Application of Climatic Data for Planning and Management of Sustainable Rainfed and Irrigated Crop Production. Agricultural and Forest Meteorology, 103, 99-108. https://doi.org/10.1016/S0168-1923(00)00121-0

[3] Behera, S.K. and Panda, R.K. (2009) Integrated Management of Irrigation Water and Fertilizers for Wheat Crop Using Field Experiments and Simulation Modeling. Agricultural Water Management, 96, 1532-1540.

https://doi.org/10.1016/j.agwat.2009.06.016

[4] Blum, A. (2009) Effective Use of Water (EUW) and Not Water-Use Efficiency (WUE) Is the Target of Crop Yield Improvement under Drought Stress. Field Crops Research, 112, 119-123. https://doi.org/10.1016/j.fcr.2009.03.009

[5] Farré, I. and Faci, J.M. (2006) Comparative Response of Maize (Zea mays L.) and Sorghum (Sorghum bicolor L. Moench) to Deficit Irrigation in a Mediterranean Environment. Agricultural Water Management, 83, 135-143.

https://doi.org/10.1016/j.agwat.2005.11.001

[6] Ali, M.H. and Talukder, M.S.U. (2008) Increasing Water Productivity in Crop Production-A Synthesis. Agricultural Water Management, 95, 1201-1213.

https://doi.org/10.1016/j.agwat.2008.06.008

[7] Fereres, E. and Soriano, M.A. (2007) Deficit Irrigation for Reducing Agricultural Water Use. Journal of Experimental Botany, 58, 147-159. https://doi.org/10.1093/jxb/erl165

[8] Debaeke, P. and Aboudrare, A. (2004) Adaptation of Crop Management to Water-Limited Environments. European Journal of Agronomy, 21, 433-446. https://doi.org/10.1016/j.eja.2004.07.006

[9] Pereira, L.S., Oweis, T., Zairi, A. and Santos, L. (2002) Irrigation Management under Water Scarcity. Agricultural Water Management, 57, 175-206. https://doi.org/10.1016/S0378-3774(02)00075-6

[10] Kipkorir, E.G., Raes, D. and Labadie, J. (2002) Optimization of the Short Term Supply of Irrigation Water for a Multicrop Scheme When Conflicts between Supply and Demand Arises. Hydraul. Eng. Softw., 8, 81-90.

[11] Richard, M.S., Allen, G., Pereira, L.S. and Raes, D. (1998) FAO Irrigation and Drainage Paper No. 56: Crop Evapotranspiration (Guidelines for Computing Crop Water Requirements). FAO, Rome.

[12] Doorenbos, J. and Kassam, A.H. (1979) Yield Response to Water. Rome.

[13] Karam, F., et al. (2007) Evapotranspiration, Seed Yield and Water Use Efficiency of Drip Irrigated Sunflower under Full and Deficit Irrigation Conditions. Agricultural Water Management, 90, 213-223. https://doi.org/10.1016/j.agwat.2007.03.009

[14] Todorovic, M., Albrizio, R., Zivotic, L., Abi Saab, M.T., Stöckle, C. and Steduto, P. (2009) Assessment of Aquacrop, Cropsyst, and WOFOST Models in the Simulation of Sunflower Growth under Different Water Regimes. Agronomy Journal, 101, 509-521. https://doi.org/10.2134/agronj2008.0166s

[15] Staff, S.S. (1975) Soil Taxonomy. 1-754.

[16] van Genuchten, M.T. (1980) A Closed-Form Equation for Predicting the Hydraulic Conductivity of Unsaturated Soils. Soil Science Society of America Journal, 44, 892-898.https://doi.org/10.2136/sssaj1980.03615995004400050002x

[17] Fine, A.K., van Es, H.M. and Schindelbeck, R.R. (2017) Statistics, Scoring Functions, and Regional Analysis of a Comprehensive Soil Health Database. Soil Science Society of America Journal, 81, 589-601. https://doi.org/10.2136/sssaj2016.09.0286 